\title{
A Method Proposal to Increase the Efficiency of Photovoltaic Panels Integrated to Buildings in Both Cold and Hot Seasons
}

\author{
Derin ALGÜL ${ }^{1(D)}$, A. Cüneyd DiRi 2* (D) \\ ORCID 1: 0000-0002-3445-7274 \\ ORCID 2: 0000-0001-8122-9568 \\ ${ }^{1}$ Enka Schools, International Baccalaureate, 34460, Istanbul, Turkey. \\ ${ }^{2}$ Mimar Sinan Fine Arts University, Faculty of Architecture, Department of Architecture, 34427, Istanbul, Turkey. \\ *e-mail: acdiri@gmail.com
}

\begin{abstract}
One of the biggest parts in world energy consumption belongs to buildings. Therefore, building designers are increasingly concerned with energy problems and turning to renewable energy sources. The most widely used systems in renewable energy use in buildings are photovoltaic panels. Studies on the efficiency of photovoltaic panels and the parameters that affect them continue today. One of the factors affecting the energy production of photovoltaic panels is panel temperature. There are many studies in the literature that have tried different methods for cooling panels that are overheated under intense radiation. In this study, with the "Thermoelectric Effect" method, it is aimed to increase the panel efficiency by solving both the heating problem of the photovoltaic panels used in buildings during the summer seasons and the snowfall of the panels in the winter seasons. In the study, experiments were made on the pilot model, and the applicability of the method was shown with the calculations made in the light of the results.
\end{abstract}

Keywords: Solar radiation, energy, photovoltaic panel, overheating, thermoelectric module, efficiency

\section{Binalarda Kullanılan Fotovoltaik Panellerin Soğuk ve Sıcak Mevsimde Verimini Arttıracak Bir Yöntem Önerisi}

Öz

Dünya genelinde enerji tüketimindeki en büyük paylardan biri binalara aittir. Dolayısıyla bina tasarımcıları giderek daha fazla enerji sorunuyla ilgilenmeye ve yenilenebilir enerji kaynaklarına yönelmeye başlamışlardır. Binalarda yenilenebilir enerji kullanımında en yaygın olarak kullanılan sistemler fotovoltaik panel sistemleridir. Fotovoltaik panellerin verimliliğini etkileyen parametrelerle ilgili çalışmalar günümüzde de devam etmektedir. Fotovoltaik panellerin enerji üretimini etkileyen faktörlerden bir tanesi panel sıcaklığıdır. Literatürde, yoğun radyasyon altında aşııı ısınan panellerin soğutulmasıyla ilgili farklı yöntemlerin denendiği çok sayıda çalışma bulunmaktadır. Bu çalışmada, "Termoelektrik Etki" yöntemiyle, binalarda kullanılan fotovoltaik panellerde yaz mevsimlerinde görülen ısınma sorununa ve kış mevsimlerinde panellerin kar altında kalmasına çözüm getirilerek panel verimliliğinin artııııması amaçlanmıştır. Çalışmada pilot model üzerinde deneyler yapılmış, elde edilen sonuçlar ışığında yapılan hesaplamalarla yöntemin uygulanabilirliği gösterilmiştir.

Anahtar kelimeler: Güneş radyasyonu, enerji, fotovoltaik panel, ısınma, termoelektrik modül, verim

Atıf/Citation: Algül, D, Diri, A. C. (2021). A Method Proposal to Increase the Efficiency of Photovoltaic Panels Integrated to Buildings in Both Cold and Hot Seasons. Journal of Architectural Sciences and Applications, 6 (1), 227-236. DOI: 10.30785/mbud.909787 


\section{Introduction}

Research and investment in renewable energy sources is increasing in order to solve the growing energy needs with the developing technology. One of the largest shares in the global energy consumption distribution in the world belongs to the construction sector. On average, buildings have a $30 \%$ share in energy consumption and a $50 \%$ share in global electricity consumption worldwide. $1 / 3$ share in global carbon emissions also belongs to buildings. Today, with the use of renewable energies, buildings are designed not as energy consumers but as energy producers. Hereof, legal regulations have been made and investment incentives and government supports have been given. The sections allocated to energy generating systems on the building are called the "energy footprint of the building". Concerning the subject, the concepts of "energy efficient building" and "zero energy building" are becoming widespread (Gokmen, 2016; TSKB, 2020).

There are two basic principles to minimize the use of energy obtained from fossil fuels in buildings. One of them is the minimization of the energy demand of the building with passive measures and the other is the maximum utilization of renewable energies. Heating, cooling and electrical energy are required for the use of buildings. The energy used in heating or cooling can be significantly reduced with effective thermal insulation applications and passive methods. Therefore, it comes to the fore to meet the electrical energy demand by using renewable energy (Kim, 2015).

The easiest and most reliable way to obtain electrical energy using renewable energy in buildings is photovoltaic panels. In addition to the issues such as the suitability of the building, cost, service life, reimbursement and aesthetics, which are taken into consideration when integrating photovoltaic panels into buildings, studies on improving the efficiency of photovoltaic panels have gained importance in recent years. The efficiency of the panels depends on multiple parameters. However, the main factor that determines the amount of electrical energy to be obtained is the intensity of solar radiation falling on the panel. A standard photovoltaic panel can convert $15-20 \%$ of the radiation falling on it into electrical energy. More than half of the radiation is converted into heat energy on the panel. This causes an increase in panel temperature and a decrease in output voltage values and power losses (Bigot, 2010; Gökmen, 2016; Taqwa, 2019).

Photovoltaic panels placed in open areas can transfer some of their heat to the air thanks to the freely circulating air currents around them. In applications on roofs or facades in buildings, since there is usually not enough space between the panel and the rear surface, it is more difficult for the panels to give heat by convection. Therefore, the problem of heating comes to the fore in photovoltaic panels integrated into buildings. In field measurements, it has been observed that the working temperatures of silicon-based photovoltaic panel cells under the sun rise up to $40^{\circ} \mathrm{C}$ above the ambient temperature (Carlos, 2021; Ezan, 2018; Makki, 2015).

PV Panel manufacturers give the efficiency values of the panels they produce for standard operating conditions $\left(1000 \mathrm{~W} / \mathrm{m}^{2}\right.$ radiation density, $1.5 \mathrm{AM}$ air mass, $1 \mathrm{~m} / \mathrm{s}$ wind speed and $25{ }^{\circ} \mathrm{C}$ panel temperature). Each $2^{\circ} \mathrm{C}$ increase above the standard operating temperature causes approximately $1 \%$ efficiency loss in the panel. In addition, thermal stresses caused by overheating of photovoltaic panels may also cause structural damage to the panel. Therefore, it can be said that the two main factors that directly affect the photovoltaic panel electricity generation are radiation and temperature. Maximum efficiency will be achieved by ensuring that the panels receive the maximum amount of radiation and minimizing the panel surface temperature (Arifin, 2020; Elminshawy, 2019; Gökmen, 2016).

Another factor that causes a decrease in the efficiency of the panels depending on the seasonal conditions is precipitation. Panel efficiency may drop very high, especially due to snow accumulation on the panels, therefore, even energy production may stop completely.

In this study, a temperature controlled photovoltaic panel has been developed that can be used on the roofs or facades of buildings. In the study, it is aimed to work more efficiently in the hot season and cold season by adding a thermoelectric module, fan and temperature control unit to the panel. 


\section{A Brief Overview of Panel Cooling Methods}

Photovoltaic cell is the name given to energy generation modules that generate electricity from light. Generally, a photovoltaic cell is almost entirely made of silicon, the second most abundant element in the Earth's crust, and more than $90 \%$ of commercially available photovoltaic cells today are based on a single or polycrystalline semiconductor material produced with silicon. It has no moving parts; therefore, it can theoretically work stably for a very long time. Photovoltaic cells combine to form solar panels and output as a potential difference (Fraunhofer, 2020; Open University Courses).

Photovoltaic cells, which were discovered at the beginning of the 19th century and started to be used in buildings towards the end of the 20th century, have become increasingly widespread with their developing technologies, and have become an indispensable part of buildings with zero or nearzero energy. Today, photovoltaic cells can be applied to non-transparent parts of the building shell, as well as to light-transmitting parts such as atrium cover, skylight, etc. Photovoltaic systems can be associated with the architecture during the design phase of the building or by adding it later to an existing building and they can be used only in energy production in the building or undertake other functions. For example, photovoltaic panels can be used as the building roof or facade cladding element (finishing) during the construction of the building or in retrofit applications made afterwards or they can be designed separately such as double façade systems, canopies or solar control elements. The size, location and shape of photovoltaic systems in the building envelope will affect the building aesthetics as well as efficiency (Gökmen, 2016).

High intensity solar radiation falls on the surfaces of solar panels used in buildings or open areas, depending on the latitude of the region in which it is located. Therefore, the period when the panels work with the highest efficiency is the summer period. However, high intensity radiation often heats the panel surface extremely. Silicon or similar semiconductor materials that make up photovoltaic cells deteriorate over time, which causes a decrease in panel efficiency and a decrease in service life (Du, 2012; Makki, 2015).

To prevent overheating of photovoltaic panels used in buildings, many methods have been tried, simulations and tests have been carried out using different heat transfer paths. Among these, methods based on convection, radiation, and evaporation, using phase-transformed materials and thermoelectric materials can be counted.

In convection-based cooling, one of the old and classical methods used in buildings, in which water or air is used as a fluid in pipe or channel systems integrated with the panel. Liquid cooling is faster than air cooling. Passive convective cooling takes place by natural circulation. Active cooling includes elements such as a fan or pump that accelerate the circulation by using additional electrical energy. However, with the introduction of additional equipment in this type of circulation-based cooling, problems such as cost increase, maintenance requirement and increase in system weight resulting in taking up more space will come with it (Du, 2012).

Instead of conventional water pipes, by using $1 \mathrm{~mm}$. or smaller diameter hollow polymeric fibers, the system was turned out to be lighter and more compact. However, it is said that a further research on the economic viability and durability of the proposed fiber cooling system should be done. (Raudensky, 2015).

Another method studied, the solar chimney method, is based on cooling the panels with air flow. In the method, chimneys attached to the panels are used and the air-lifting effect of the chimney is taken advantage of. As the chimney length increases, the air velocity withdrawn increases. However, the shading effect of the chimneys and the economic and aesthetic aspects of the application make it difficult to apply the method to the buildings (Sh-Eldin, 2013).

Other recommended methods of passive cooling of photovoltaic panels with air include adding aluminum heatsinks with blades on the solar panel to increase the surface in contact with air or on the panel to accelerate the air flow between the back of the panel and the front face (optimizing the space-occupancy ratio) by opening air passage gaps. However, in the first method, additional surfaces which are not used in electrical energy production is added to the panels so there is an 
increase in weight. In the second, there is a loss of area on the panel surface (Abd-Elhady, 2018; Arifin, 2020).

Another negative side of the convective cooling methods mentioned in this section, in which air is used as a refrigerant in hot climatic regions where the need for cooling is higher, is that the circulation air cannot be effective in cooling the panels due to the high air temperature. To work out the problem, studies have been carried out on another convective cooling method, geothermal cooling. In this method, air ducts go down to a certain depth under the soil to cool the ambient air. However, additional equipment is required for air circulation and heat transfer (Elminshawy, 2019).

Another method used to cool the panels is to spray water particles on the panel with pipe systems with nozzles. This evaporation-based method is more effective than air cooling. The system can operate with natural water pressure or a direct current pump, but the use of water whilst the system is working makes it difficult to use the method in arid or highwater demand areas (Elnozahy, 2015; Irwan, 2015).

Apart from the methods mentioned above, many studies have been conducted on the use of phasechanging materials in panel cooling. In the selection of organic or inorganic phase-changing materials to be used in the system, properties such as the amount of latent heat absorbed, freezing point, and thermal stability are considered. In addition, properties such as unresponsiveness to chemical substances, environmental friendliness and low cost, and non-toxicity are also sought in the material (Adeel Waqas, 2018; Fazri, 2019).

Another method that has been studied in the passive cooling of panels in recent years is radiation cooling. Radiative cooling is more effective on horizontal surfaces. In the method, it is recommended to apply transparent and thin layers based on silicone or polymer with high thermal radiation emitting properties on the panel to reduce the surface temperature (Zhu, 2014).

Thermoelectric Cooling Method: Thermoelectric converters are two-way modules (that can convert heat energy into electricity or convert electricity into heat energy). If a temperature difference is created between the two surfaces of the module, a potential difference occurs between these two surfaces and the module can operate like a current generator. If an electrical potential difference is applied between two surfaces, one surface of the module heats up while the other surface cools. The heating and cooling of the surfaces depends on the direction of the applied tension. Thanks to these properties, the thermoelectric module can be used to generate electricity, as well as to heat, cool, measure or control the temperature of objects (Ahiska \& Ahiska, 2007).

Thermoelectric effect definition: It includes three concepts: "Seebeck Effect", "Peltier Effect" and "Thomson Effect". Peltier and Seebeck effects are opposite to each other and are the basis of the thermoelectric effect. Therefore, the thermoelectric effect is referred to as the "Peltier - Seebeck Effect" in the literature (Ahiska, 2007).

There are various studies in the literature where thermoelectric modules are used by exchanging energy with photovoltaic panels. Among these are hybrid systems where thermoelectric modules are used as thermoelectric current generators with photovoltaic panels and air conditioning systems in which electrical energy from photovoltaic panels is used as cooler or heater. In panel cooling works with thermoelectric effect. Thermoelectric modules are used as surface coolers with the electrical energy they receive from photovoltaic panels (Benghanem, 2016; Choi, 2010).

In this study, the thermoelectric module was used to control the surface temperature of the panel (both in heating and cooling). In the experiments, thermoelectric module, temperature control unit, battery and fan modified photovoltaic panel were used. The battery charged by the photovoltaic panel feeds the thermoelectric module. 


\section{The Experiment and Findings}

\subsection{Presentation of the Experimental Equipment}

Two of $41.5 \mathrm{~cm} / 35.5 \mathrm{~cm}$ sized polycrystalline-based standard photovoltaic panel with $2 \mathrm{amp}, 2 \times 12$ volts and $2 \times 5$ volts outputs were taken for the experiment, and one of them was modified for the purpose. The modified panel is shown in picture 2 , and the modifications on the panel are listed below:

- The back surface of the panel is covered with aluminum plate for homogeneous temperature distribution,

- Charge control circuit prepared,

- Thermal paste is applied and thermoelectric module is fixed to aluminum plate,

- Fan and Battery installed,

- Electronic system consisting of temperature control sensor and charge control circuit was installed.

Components used in the pilot model are listed below:

- 20 watts polycrystalline photovoltaic panel (OEM)

- Thermoelectric module (TEC1-12706)

- Cooler fan (Evercool CS 1230R)

- 12 volts 7 amps accumulator (Yuasa)

- Digital display screen OEM

- Temperature control sensor OEM

- Circuit elements (Integrated circuit, resistor, diode, and capacitor)

- Aluminum coolers, case

- Connection cables, terminals, sockets

- Thermal paste

In this study, "Peltier Effect" was used in experiments conducted in summer and winter conditions. The lower and upper threshold temperatures can be adjusted according to the desired degree. Schematic representation of thermoelectric module is shown in picture 2. The technical specifications of the thermoelectric module used for the control of the panel temperature are given in Table 1, and the detailed technical specifications of the panel are given in Table 2.

Table 1. Thermoelectric module properties used in the study (Alldatasheet, 202)

\begin{tabular}{lcc} 
Warming face temperature $\left[{ }^{\circ} \mathrm{C}\right]$ & $\mathbf{2 5}$ & $\mathbf{5 0}$ \\
\hline $\mathrm{Q}_{\max }[\mathrm{W}]$ & 50 & 57 \\
\hline$\Delta \mathrm{T}_{\max }\left[{ }^{\circ} \mathrm{C}\right]$ & 66 & $\mathbf{7 5}$ \\
\hline $\mathrm{I}_{\max }[\mathrm{A}]$ & 6.40 & 6.40 \\
\hline $\mathrm{V}_{\max }[\mathrm{V}]$ & 14.40 & 16.40 \\
\hline Module resistance $[\Omega]$ & 1.98 & 2.30 \\
\hline
\end{tabular}

Table 2. Technical specifications of polycrystalline photovoltaic panel

\begin{tabular}{ll} 
Maximum Power & $\mathbf{2 0 ~ W p}$ \\
\hline Power Tolerance & $+-\% 3$ \\
\hline Open Circuit Voltage (Voc) & $22.51 \mathrm{~V}$ \\
\hline Short Circuit Current (Isc) & $1.12 \mathrm{~A}$ \\
\hline Maximum Power Voltage & $18.68 \mathrm{~V}$ \\
\hline Maximum System Voltage & $1000 \mathrm{~V}$ \\
\hline Dimensions & $415 / 355 / 25 \mathrm{~mm}$ \\
\hline Weight & $2100 \mathrm{~g}$ \\
\hline
\end{tabular}




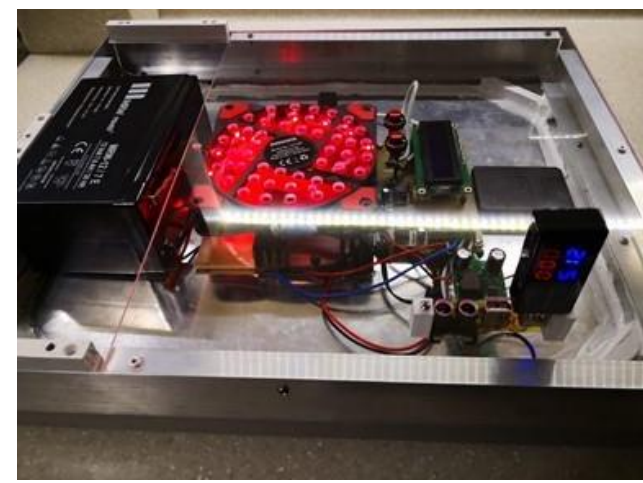

Figure 1. Modified panel used in the experiment

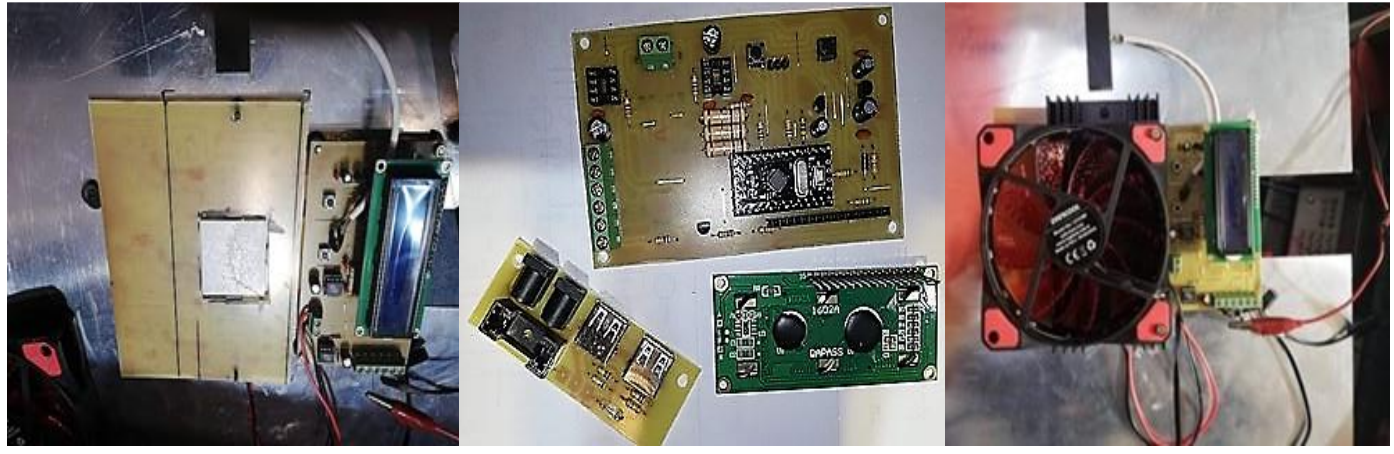

Figure 2. Components of main circuit

\subsection{Method}

In the experiments conducted in this study, the formula which gives the optimum panel slope for a fixed photovoltaic panel that can be used at all times of the year is used:

"Panel inclination degree $=$ Latitude $\times 0.87+3.1 "$

The formula that gives the angle between the panel plane and the horizontal plane can be used in the latitude range of 25 degree -50 degree. Experiments were carried out in Kocaeli Karamürsel and Kocaeli Kartepe districts with latitude 40.7 degree. The panels were oriented to the south by adjusting the angle between the panel plane and the horizontal plane to 38.5 degree according to the formula (Emre, 2021).

One modified and one standard panel (witness sample) was used in the summer conditions test. In the modified panel, the voltage direction is adjusted to cool the panel in the set panel temperature range. From the beginning of the experiment, modified panel and standard panel temperatures and corresponding output voltage values were measured.

One modified panel was used in the winter conditions test. The voltage direction on the panel is adjusted to give heat to the panel within the set panel temperature range. After the panel surface was covered with snow, the experiment was started and the output voltage values depending on the time were measured.

\subsection{Conducting the Experiment and Findings}

Summer conditions experiment: Summer conditions experiments were carried out in Karamürsel. Kocaeli. In the experiments, the modified panel and the standard panel were placed facing south with an angle of inclination of 38.5 degree. In the modified panel, the temperature control sensor is set to the critical upper threshold surface temperature of $40^{\circ} \mathrm{C}$ and the lower threshold temperature of $30^{\circ} \mathrm{C}$. The experiments were conducted on July25, July 26 and August 02,2020 and average values are given in the data tables. The experiments were carried out on a clear day, without clouds and all the experiments were started at 13:00 and 10 minutes. The surface temperatures of the panels and their output voltage values were measured at intervals. The air temperature measured in the first experiment was $29^{\circ} \mathrm{C}$, the air temperature measured in the second experiment was $28^{\circ} \mathrm{C}$, and the air temperature measured in the third experiment was $30^{\circ} \mathrm{C}$. 
After the experiments were started, it was observed that the cooling system of the modified panel was automatically activated at an average of 38 minutes and stopped operating by bringing the panel to the lower threshold temperature at an average of 83 minutes. Average 90 minutes from the beginning of the experiment. Then the standard panel reached an average thermal equilibrium temperature of $56,2^{\circ} \mathrm{C}$. In the experiments, measurements were made up to the $110^{\text {th }}$ minute. The average temperature degrees of the panels are given in table 3 and table 4 , and the measured average output voltage values are given in table 5 and table 6 .

Table 3. Average surface temperatures of standard panel in summer condition

\begin{tabular}{cccc} 
Hour & Temperature $\left[{ }^{\circ} \mathbf{C}\right]$ & Hour & Temperature $\left[{ }^{\circ} \mathbf{C}\right]$ \\
\hline 13:00 & 29.1 & $14: 00$ & 51.3 \\
\hline $13: 10$ & 29.9 & $14: 10$ & 54.0 \\
\hline $13: 20$ & 33.2 & $14: 20$ & 55.5 \\
\hline $13: 30$ & 37.4 & $14: 30$ & 56.2 \\
\hline $13: 40$ & 42.2 & $14: 40$ & 56.1 \\
\hline $13: 50$ & 47.8 & $14: 50$ & 56.2
\end{tabular}

Table 4. Average surface temperatures of the modified panel in summer condition

\begin{tabular}{cccc} 
Hour & Temperature $\left[{ }^{\circ} \mathbf{C}\right]$ & Hour & Temperature $\left[{ }^{\circ} \mathbf{C}\right]$ \\
\hline $13: 00$ & 29.1 & $14: 00$ & 40.4 \\
\hline $13: 10$ & 29.8 & $14: 10$ & 36.2 \\
\hline $13: 20$ & 33.0 & $14: 20$ & 31.5 \\
\hline $13: 30$ & 37.2 & $14: 30$ & 31.7 \\
\hline $13: 40$ & 41.9 & $14: 40$ & 32.3 \\
\hline $13: 50$ & 41.7 & $14: 50$ & 33.9
\end{tabular}

Table 5. Average output voltage values depending on the standard panel summer condition temperature

\begin{tabular}{cccc} 
Temperature $\left[{ }^{\circ} \mathbf{C}\right]$ & Voltage $[\mathrm{V}]$ & Temperature $\left[{ }^{\circ} \mathbf{C}\right]$ & Voltage $[\mathrm{V}]$ \\
\hline 29.1 & 13.1 & 51.3 & 12.1 \\
\hline 29.9 & 13.1 & 54.0 & 11.5 \\
\hline 33.2 & 13.0 & 55.5 & 11.3 \\
\hline 37.4 & 13.0 & 56.0 & 11.2 \\
\hline 42.2 & 12.8 & 56.1 & 11.2 \\
\hline 47.8 & 12.7 & 56.0 & 11.2
\end{tabular}

Table 6. Modified panel, average output voltage values depending on summer condition temperature

\begin{tabular}{cccc} 
Temperature $\left[{ }^{\circ} \mathrm{C}\right]$ & Voltage $[\mathrm{V}]$ & Temperature $\left[{ }^{\circ} \mathrm{C}\right]$ & Voltage $[\mathrm{V}]$ \\
\hline $29.1^{\circ} \mathrm{C}$ & 13.2 & 40.4 & 12.9 \\
\hline $29.8^{\circ} \mathrm{C}$ & 13.2 & 36.2 & 12.9 \\
\hline $33.0^{\circ} \mathrm{C}$ & 13.1 & 31.5 & 13.1 \\
\hline $37.2^{\circ} \mathrm{C}$ & 13.0 & 31.7 & 13.1 \\
\hline $41.9^{\circ} \mathrm{C}$ & 13.0 & 32.3 & 13.1 \\
\hline $41.7^{\circ} \mathrm{C}$ & 12.8 & 33.9 & 13.0
\end{tabular}

In the summer conditions experiment, it was observed that after the temperature of the standard panel increased by $27^{\circ} \mathrm{C}$, it reached the thermal equilibrium and the output voltage decreased by $15 \%$ on average at this temperature. It was observed that the temperature of the panel controlled by the thermoelectric module was the highest average value of $41,9{ }^{\circ} \mathrm{C}$, and the output voltage decreased by an average of $3 \%$ at this temperature.

Winter conditions experiment: The winter conditions experiment was carried out on February 09, 2020, at an ambient temperature of $3{ }^{\circ} \mathrm{C}$ in Kartepe, Kocaeli. In the experiment, as expected, a decrease in energy efficiency was observed in proportion to the increase in the amount of snow cover on the panel surface, and the efficiency decreased to zero when the panel surface was completely covered with snow. With the activation of the heating system at $4{ }^{\circ} \mathrm{C}$, the energy efficiency started to increase again after 2 minutes. In $14^{\text {th }}$ minutes the panel surface was completely cleaned, and the loss of efficiency was eliminated. The results obtained are given in Table 7. 


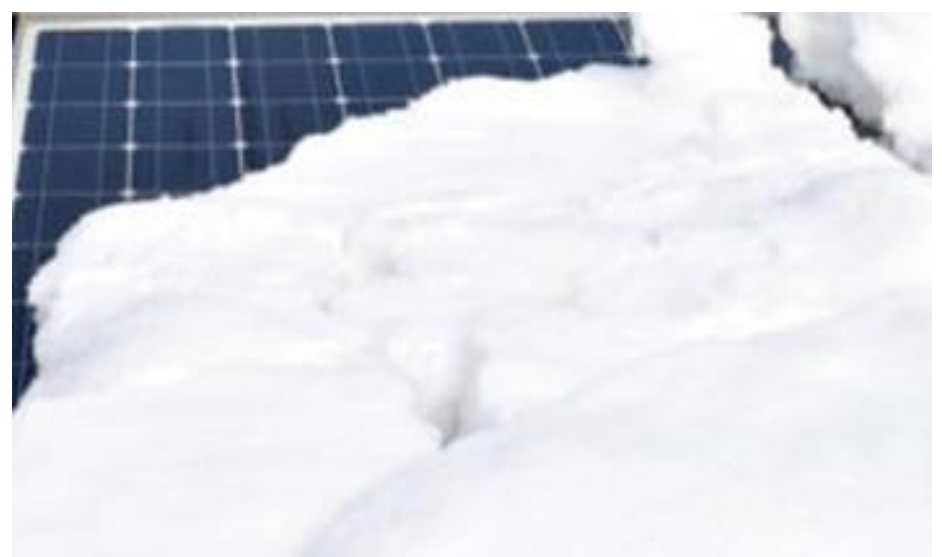

Figure 3. Winter condition experiment

Table 7. Modified panel output voltage values depending on time in winter conditions

\begin{tabular}{cccc} 
Time [min] & Volt & Time [min] & Volt \\
\hline 00 & 0.0 & 08 & 08.4 \\
\hline 01 & 0.0 & 09 & 08.8 \\
\hline 02 & 0.8 & 10 & 09.2 \\
\hline 03 & 2.1 & 11 & 10.2 \\
\hline 04 & 4.3 & 12 & 11.5 \\
\hline 05 & 5.1 & 13 & 12.9 \\
\hline 06 & 6.3 & 14 & 13.2 \\
\hline 07 & 7.6 & 15 & 13.3 \\
\hline
\end{tabular}

\section{Conclusion and Discussion}

In this study, the thermoelectric module was used in two directions to control the surface temperature of the panel, both cooling and heating. In the experiment carried out under winter conditions, the snow cover that completely covered the panel was removed within 14 minutes, while an average of $15 \%$ reduction in efficiency was observed in the standard panel in the experiment performed in summer conditions, while an average efficiency reduction of $3 \%$ was observed in the panel cooled by thermoelectric effect. The experiment was carried out in the Marmara Region, which has mild climate characteristics. The difference will be wider in more extreme climatic conditions.

The system works by taking the activation energy from the system's battery. Thermoelectric modules draw high current for a short time while heating and cooling, they use this current from the battery, and this current corresponds to $3 \%$ of the total battery energy. The energy used from the panel system produced in this study is negligible compared to the energy gained.

The designed system is attached to the back of the panel, with a standard 20-watt size of $41.5 \mathrm{~cm} /$ $35.5 \mathrm{~cm}$. It is easy to assemble and move and does not require an additional system outside the panel. When the panel sizes are increased, the aluminum plate surface area and the number of thermoelectric modules will increase, other material costs will remain the same. The system increased the cost of the standard photovoltaic panel by $40 \%$. However, it will be clearly seen that it is more advantageous when it is considered that the panel will provide more than $50 \%$ efficiency increase every year in summer and winter and the average service life is 20 years.

\section{Acknowledgment and Information}

No assistance was received from any institution or organization in the study. The article complies with national and international research and publication ethics. Ethics committee permission was not required for the study.

\section{References}

Abd-Elhady, M. S., Serag, Z., Kandil, H. A. (2018). An Innovative Solution to the Overheating Problem of PV Panels. Energy Conversion and Management Volume 157, 1 February 2018, Pages 452 459. 
Adeel Waqas, J. J. (2018). Effectiveness of Phase Change Material for Cooling of PV Panel for Hot Climate. Journal of Solar Energy Engineering Aug 2018, 140(4): 041006 (10 pages).

Ahiska, R., Ahiska, K. (2007). Flexible Two-Phase Thermoelectric CPU Cooler. Journal of the Faculty of Engineering and Architecture of Gazi University, 22 (2), Pages 347-351.

Ahiska, R. (2007). New Method for Study Dynamic Exit Properties of Thermoelectric Modules. Journal of the Faculty of Engineering and Architecture of Gazi University, 22 (4), Pages 709-716.

Alldatasheet Electronic Components Datasheet Search. Thermoelectric Cooler Performance Specifications. Access address (03 03 2021). https://www.alldatasheet.com/datasheetpdf/pdf/227422/ETC2/TEC1-12706.html

Arifin, Z., Suyitno, S., Tjahjana, D. D. D. P., Juwana, W. E., Putra, M. R. A., Prabowo, A. R. (2020). The Effect of Heat Sink Properties on Solar Cell Cooling Systems. Applied Sciences, Published: 8 November 2020 Doi: 10.3390

Benghanem, M., Al-Mashraqi, A. A., Daffallah, K. O. (2016). Performance of Solar Cells Using Thermoelectric Module in Hot Sites. Renewable Energy, April 2016, Volume 89, Pages 51-59.

Bigot, D., Miranville, F., Fakra, A. H., Ingar, I., Guichard, S., Boyer, H. (2010). Thermal Performance of Photovoltaic Systems Integrated in Buildings. Researchgate Publication No: 221905612, October 2010, Doi: 10.5772/10347.

Carlos, Can Solar Panels Overheat? (2021). Access address (03 03 2021): https://ecotality.com/cansolar-panels-overheat/

Choi, J. S., Ko, J. S., Chung, D, H. (2010). Development of a Thermoelectric Cooling System for a High Efficiency BIPV Module. Journal of Power Electronics, 2010. Mar, 10 (2), p 187-193.

Du, B., Hub, E., Kolhec, M. (2012). Performance Analysis of Water Cooled Concentrated Photovoltaic (CPV) System. Renewable Sustainable Energy Reviews, Volume 16, December 2012, Pages 6732-6736.

Elminshawy, N. A. S., Mohamed, A. M. I., Morad, K., Elhenawy, Y., Alrobaian, A, A. (2019). Performance of PV Panel Coupled with Geothermal Air-Cooling System Subjected to Hot Climatic. Applied Thermal Engineering, Volume 148, 5 February 2019, Pages 1-9.

Elnozahy, A., Abdel Rahman, A. K., Ali, A. H. H., Abdel-Salam, M., Ookawara, S. (2015). Performance of a PV Module Integrated with Standalone Building in Hot Arid Areas as Enhanced by Surface Cooling and Cleaning. Energy and Buildings, Volume 88, 1 February 2015, Pages 100-109.

Emre, Y. (2021). Güneş Paneli (Solar Panel) Açısı Nasıl Hesaplanır. Access address (02 03 2021): https://www.aydinlatma.org/gunes-paneli-solar-panel-acisi-nasil-hesaplanir.html

Ezan, M. A., Yüksel, C., Alptekin, E., Yılancı, A. (2018). Importance of Natural Convection on Numerical Modelling of the Building Integrated PVP/PCM Systems. Solar Energy, Volume 159, 1 January 2018, Pages 616-627.

Gokmen, N., Hu, W., Hou, P., Chen, Z., Sera, D., Spataru, S. (2016). Investigation of Wind Speed Cooling Effect on PV Panels in Windy Locations. Renewable Energy, Volume 90, May 2016, Pages 283-290.

Fazri, Rizal, T. A., Amin, M., Hamdani, (2019). Performance Evaluation on PV Panels with Cooling Optimization Utilizing Phase Changing Materials. International Conference on Science, and Innovated Engineering, doi:10.1088/1757-899X/536/1/012082.

Fraunhofer Institute for Solar Energy Systems (2020). Fraunhofer ISE - Annual Report 2020/21. Access address (02 03 2021): https://www.ise.fraunhofer.de

Irwan, Y. M., Leow, W. Z., Irwanto, M., Fareq, M., Amelia, A. R., Gomesh, N., Safwati, I. (2015). Indoor Test Performance of PV Panel through Water Cooling Method. Science Direct, Energy Procedia Volume 79, November 2015, Pages 604-611. 
Kim, J. H., Kim, H. R., Kim, J. T. (2015). Analysis of Photovoltaic Applications in Zero Energy Building. Sustainability 2015, 7, 8782-8800; doi:10.3390/su7078782.

Makki, A., Omer, S., Sabir, H. (2015). Advancements in Hybrid Photovoltaic Systems for Enhanced Solar Cells Performance. Renewable and Sustainable Energy Reviews, Volume 41, January 2015, Pages 658-684.

Open University Courses. Basic Physical Principles of Photovoltaics. Access address (03 02 2021). https://www.open.edu/openlearn/ocw/mod/oucontent/view.php?id=73760\&section=2.

Raudensky, M., Astrouski, I., Reppich, M., Schmidt, M. (2015). Solar Panel Cooling System with Hollow Fibres. Third Southern African Solar Energy Conference, Kruger National Park, South Africa, 11-13 May 2015.

Sh-Eldin, M., Sopian, K., Alghoul, F. O., Abouhnik, A., Muftah, M. (2013). Solar Chimney Model Parameters to Enhance Cooling PV Panel Performance. Modern Applied Science; Vol. 7, No. 2.

Taqwa, A., Dewi, T., Kusumanto, R. D., Sitompul, C. R., (2019). Automatic Cooling of a PV System to Overcome Overheated PV Surface in Palembang. Journal of Physics: Conference Series doi:10.1088/1742-6596/1500/1/012013.

TSKB Rapor. Enerji Görünümü. (2020). Access address $\left.\begin{array}{llll}03 & 02 & 2021\end{array}\right)$. https://www.tskb.com.tr/i/assets/document/pdf/enerji-sektor-gorunumu-2020.pdf.

Zhu, L., Raman, A., Wang, K. X., Anoma, M. A., Fan, S. (2014). Radiative Cooling of Solar Cells. Vol. 1, No. 1 / July 2014 / Optica. 